\title{
Optimization Of Broiler Production And Immune Response Through Giving Meniran (Phyllanthus Niruri L) And Sambiloto (Andrographis Paniculata) Extracts After Nd Vaccination
}

\author{
${ }^{1}$ Puji Astuti and ${ }^{1}$ Heru Suripta \\ ${ }^{1}$ Akademi Peternakan Karanganyar \\ Coresponding author : tutiamir88@gmail.com
}

\begin{abstract}
This study aims to determine the effect of differences in herbal composition of meniran and sambiloto extracts on the production and immune response of chicken broilers. The study was conducted at the Karanganyar Animal Husbandry Academy. The study used 60 broiler chicken divided into 4 treatment groups and 3 repeat treatments. The treatment applied was the composition of meniran and bitter with oral as much as $300 \mathrm{mg} / \mathrm{kg}$ body weight, including: $\mathrm{T} 0$ (Control): without of meniran and sambiloto extracts, T1: giving of meniran and sambiloto extract with a composition of 75: $25 \%$, T2: giving of meniran and sambiloto extract with a composition of 50: 50\%, T3: giving of meniran and sambiloto extract with a composition of 25: 75\%. The design used is a complete random design. The parameters observed include 1. production display includes feed consumption, final body weight, carcass percentage, and abdominal fat; 2 . immune responses include ND titers, and lymphocytes. Production display data were analyzed using analysis of variance, antibody titers and lymphocytes were reported descriptively. Based on the results of the analysis of the giving of meniran and sambiloto extracts with different compositions did not affect the consumption of drinking water, feed consumption, final body weight, and carcass percentage. The percentage of abdominal fat is influenced by differences in the composition of the meniran and sambiloto extract (sig. 0.023). ND titers from day 0 to day 21 after being vaccinated reached protective numbers, while on day 28 the ND titers decreased. Giving more meniran extract (75: 25\%) has a higher titer than controlled group. Lymphocyte counts during the study were under normal conditions for all treatments. It was concluded that differences in the composition of meniran and bitter extract affect the percentage of abdominal fat, but did not affect the final body weight and percentage of carcass. Giving meniran and bitter extract can improve chicken immunity.
\end{abstract}

Keywords: immune response, meniran extract and bitter, production optimization.

\section{Introduction}

Rapid increase in chicken broiler meat consumption causes raising chicken broilers have good prospects. This is caused by the rapid growth rate of broilers and can convert the ration consumed optimally into meat. However, broilers have some bad nutritional factor, one of which is excessive fat deposition.

The final weight of the broiler during harvest will affect the conversion value of the ration. Smaller feed conversion indicates the better performance of the broiler. Some 
efforts that can be done to improve the performance of broilers are through the use of vitamins, vaccines, chemical drugs, and antibiotics. However, the use of chemical drugs and antibiotics in the maintenance of broiler continuously with high doses can cause drug residues in the carcass and viscera organs. The percentage of carcasses of a chicken is closely related to the live weight of chickens at harvest. According to Suprayitno and Indraji (2007) the average weight percentage of broiler chicken carcasses aged 5 weeks is 59-63\% of body weight. While Sumarni (2015) states that the average percentage of carcass weight is $69.76-73.39 \%$.

Disease in chickens is not only caused by viruses, but also bacteria, fungus, toxins, nutrient deficiencies, and extreme environmental conditions (Mulyantini 2011). Efforts to control disease are usually by prevention and treatment. Prevention is done by vaccinating and administering antibiotics. Treatment of broiler chickens is inefficient for broiler farming.

Tetelo virus (Newcastle Disease) is a viral disease caused by Avian Pal-amyxovir $\sim$ is and classified into the RNA virus and has a target set of respiratory mucosa epithelial cells or respiratory tract. Newcastle Disease is a complex disease, thus showing variations in form and severity of the disease. This disease has an important economic impact in the poultry industry because it causes high morbidity and mortality, decrease in egg production in both quantity and quality, growth disturbance, high disease prevention costs and supports the emergence of other respiratory diseases. (Cahyono, 2019).

Until now, one of the efforts to prevent ND is by vaccination. However, vaccination can fail due to various reasons, including poultry that are immunosuppressed due to being infected with Gumboro disease, Marek's disease, or feed containing mycotoxins (Gillinghan 2006).

Immunosuppression is a state of suppressed immune response so that it may affect the vaccination response. Some experts report that suppressing the antibody response to ND viruses is very severe on the first day after infection with the Infectious Bursal Disease virus (hereinafter referred to as IBD). The suppression of antibody responses to ND viruses is moderate on the 7th day post-infection and does not cause immunosuppressive effects on the 14th or 21st day post-infection of the IBD virus (Tabbu 2000).

Some medicinal plants such as Meniran and Sambiloto have been used for generations by Indonesian people as traditional medicine. Meniran has efficacy as an antiviral drug. Compounds found in meniran include triterpenoids, flavonoids, tannins, alkaloids, and phenolic acids. Sambiloto contains Andrographolide and flavonoids have hepatoprotective, immunological potential, anti-inflammatory effects, can work on the respiratory system, antimalarial, antidiarrheal, and have good effects on the heart. . Sambiloto can increase lymphocyte proliferation and increase antibodies (Winarto 2003, Elfahmi 2009). Both of these medicinal plants both have activities that affect the immune response. Immune response is related to lymphoid organs, including the spleen. The administration of medicinal plant extract formulas is expected to have a good effect on the spleen and immune picture so that it can be considered an alternative medicine for chickens. 


\section{Materials and Methods}

The study used as many as 60 broiler chickens, divided into 4 treatments 3 repeat trements. Each repeat treatment used 5 chicken. Location of the research took place in Livestock Practice Unit of Karanganyar Animal Husbandry Academy. The ingredients used are ethanolic of meniran and sambiloto, BR 1 feed with a protein content of $21 \%$. Chickens are kept in 12 cage units, of which each was about $1 \times 1 \mathrm{~m}$ in size with 5 chickens.

The treatment applied was administration of ethanolic extract of meniran and sambiloto as much as $300 \mathrm{mg} / \mathrm{kg} \mathrm{BW}$ orally as follows:

T0 : chicken without administration of extract

T1 : chicken were given $75 \%$ meniran extract: 25 bitter extract

T2 : chickens were given $50 \%$ meniran extract: $50 \%$ bitter extract

T3 : chicken was given $25 \%$ meniran extract: $75 \%$ bitter extract

Blood samples were taken just before vaccination (Day 0), 7 days after vaccination $($ Day +7$), 14$ days after vaccination (Day +14$), 21$ days after vaccination $($ Day +21$), 28$ days after vaccination $($ Day +28$)$. Blood samples were taken from as many brachial veins / wing veins as sterile syringes for ND titer analysis, and some blood samples were made of smear using glass objects for lymphocyte level analysis. The lasota ND vaccine is given through eye drops.

\section{Ethanol Extract Making}

Meniran and Sambiloto are air dried. After drying, meniran and bitter are then grinded into fine flour. The fine flour obtained is then extracted (soaked) with ethanol in a ratio of 1: 10 for 36 hours (every day stirring), then filtered. Extraction is done 2 times (remaseration). The ethanol extract obtained was evaporated until a thick extract was obtained.

The parameters measured include, drinking water consumption, feed consumption, final body weight, carcass percentage, and abdominal fat percentage. ND titers and lymphocyte levels

Data collected (drinking water consumption, feed consumption, final body weight, percentage of carcass, percentage of abdominal fat) were analyzed for variance using a Completely Randomized Design. ND and lymphocyte titer data were analyzed descriptively.

\section{Chicken Production}

\section{Results and Discussion}

Data on drinking water consumption, feed consumption, final body weight, percentage of carcass and abdominal fat are listed in Table 1.

Table 1. Broiler Chicken production given meniran and sambiloto extract

\begin{tabular}{lrrrr}
\hline \multirow{2}{*}{ Variable } & \multicolumn{4}{c}{ Treatment } \\
\cline { 2 - 5 } & \multicolumn{1}{c}{ T0 } & \multicolumn{1}{c}{ T1 } & \multicolumn{1}{c}{ T2 } \\
\hline Drink Consumption (ml/chick/day) & 195.33 & 178.68 & 172.29 & 167.67 \\
Feed consumption (g/chick/dayi) & 82.45 & 70.24 & 72.91 & 72.00 \\
Final weight (g/echick/day) & 1314.31 & 1187.54 & 1226.95 & 1301.53 \\
Carcass percentage (\%) & 64.97 & 65.42 & 66.21 & 64.75 \\
Abdominal Fat percentage (\%) & $1.10^{\mathrm{a}}$ & $0.88^{\mathrm{b}}$ & $0.99^{\mathrm{b}}$ & $0.84^{\mathrm{b}}$ \\
\hline
\end{tabular}

Different superscripts on the same line show significant differences

Giving of meniran and sambiloto extract does not affect the consumption of broiler chicken drinking water. Wahju (1985) states that taste in chicken plays a 
relatively small role in determining the number of drinks consumed because broilers have fewer sensory nerves, only 24 compared to cows (2500-3000) so that the bitter taste in meniran and sambiloto doesn't taste bitter if consumed by chicken. According to Seto (2019), the amount of drinking water consumption is more significantly influenced by the ambient temperature, the amount and the state of feed provided.

Giving meniran and sambiloto extract does not affect the consumption of broiler chicken feed. The bitter taste in Sambiloto has not been able to stimulate appetite so it has not affected the consumption of broiler chicken feed.

Feed consumption in the treatment of meniran and bitter extract with ethanol (orally) according to the statement of Fadillah and Fakhturoji (2013) that the amount of feed consumed is related to drinking water consumption, production level, and environmental temperature

Giving meniran and sambiloto extract does not affect the final body weight of broiler chickens. According to Rasyaf (2012) supporting factors for growth of broiler chickens are feed and maintenance management. In this study, feed consumption was not different so that the final chicken body weight was the same.

In this study the percentage of carcasses that were given meniran and sambiloto extracts were not significantly different between treatments. This is because the final body weight is the same between treatments so the percentage of carcasses is also not different. According to Setiadi et al. (2011) the percentage of carcasses of a chicken is closely related to the live weight of chickens at harvest. Nahashon et al (2005), states that the factors that affect carcass weight are not only gender, age and body weight but are also influenced by strain, food, management and environment.

Meniran and sambiloto extracts give significantly different results (Sig.023) on abdominal fat. This significant effect is thought to be due to the content contained in meniran and bitter extracts. Bintang and Nataamijaya (2006) state that a decrease in fat content can occur allegedly due to stimulus that make bile fluid secretion faster. An increase in bile causes fat content to decrease because it is broken down to produce energy in the form of ATP. A lot of flour from medicinal plants such as lempu, turmeric, ginger, tea, black cumin and meniran can reduce the abdominal fat content in broilers (Bintang and Nataamijaya, 2006; Anita et al., 2012; Salam et al., 2013). According to Haro (2005) the percentage of abdominal fat in a chicken's body reaches $2-3 \%$ of the body weight. The amount varies depending on genetic factors, feed, sex, age, to the environment.

\section{Antibody titer}

Table 2. Result of Serology Test of antibody titer

\begin{tabular}{lcccc}
\hline Day- & \multicolumn{5}{c}{ Treatment $(\log$ 2 degree $)$} \\
\hline & T0 & T1 & T2 & T3 \\
\hline D0 & 3 & 3 & 4 & 3 \\
DayD+7 & 4 & 5.0 & 4.7 & 4.7 \\
D+14 & 5.0 & 6.0 & 5.7 & 5.7 \\
D+21 & 4.3 & 5.3 & 4.3 & 4.7 \\
D+28 & 2.7 & 4.0 & 3.3 & 3.3 \\
\hline
\end{tabular}


Table 2 shows that chickens before being vaccinated (Day-0) had antibody titers derived from maternal antibodies. Maternal antibodies are antibodies that originate from the parent passed on to the child (Beby, 2015). Maternal antibodies are passed down through the egg yolk which acts as a defense when chickens hatch. But the conditions are not protective. Antibody titer is said to be protective against Newcastle Desease if it has a $\log$ antibody titer of $2^{5}-2^{8}$ (Allan et al., 1978).

The majority of commercial DOCs in Indonesia have antibody titers with HI testing of ND from the parent generally in the range of 20-25 (Rahaju et al. 1991). The parent antibody titer that circulates in the DOC blood is very dependent on three main factors, namely the parent's immune status, the general condition of the DOC itself and maintenance management.

The results of the Day-7 and Day-14 titers in all treatments showed an increase in antibody titers. This is because chickens are given an active vaccine at the age of 4 days so there are antigens that stimulate antibody formation. Active vaccine antibodies will begin to form at 3-4 days after vaccination and reach protective standards at 2-3 weeks after vaccination (Anonimus, 2015). On Day -7, giving of meniran bitter extract with a composition of 75: $25 \%$ showed the highest number of antibody titers and protective conditions $(\log 25)$. Whereas the Day-14 antibody titer showed protective figures in all treatments. However, meniran and bitter extract extracts have higher antibody titers than controls. The content of flavonoids in meniran which consists of quercetin, quercitrin, filantin and nirurin function as immunomodulators, while bitter has androgapholide content that serves to inhibit the attachment of viruses to receptors on cells. (Taha, 2009).

The antibody titer on Day-21 shows a non-protective rate against ND except when administering meniran and bitter extract $75: 25 \%\left(\log 2^{5}\right)$. This shows that the giving of meniran and bitter extracts has a longer effect than other treatments. Whereas the H-28 antibody titer in all treatments is not protective. However, meniran and bitter extract 75: $25 \%$ have higher antibody titers compared to other treatments. This study shows that all treatments using meniran and bitter extract have better levels of antibody titer protection than without extract (T0) especially in the administration of meniran and sambiiloto extracts on Day-28 so that meniran and bitter extract extracts can maintain chicken immune response even though the antibody titer is not protective against the Newcastle Disease (ND) virus.

\section{Lymphocytes}

Table 3. Amount of Lymphocytes (\%)

\begin{tabular}{lllll}
\hline Day- & \multicolumn{4}{c}{ Treatment } \\
\hline & T0 & T1 & T2 & T3 \\
\hline D-0 & 61 & 54 & 54 & 54 \\
\hline D-7 & 61 & 65 & 79 & 78 \\
\hline D-14 & 58 & 60 & 81 & 67 \\
\hline D-21 & 66 & 41 & 68 & 63 \\
\hline D-28 & 39 & 47 & 51 & 60 \\
\hline
\end{tabular}


Yalcinkaya et al. (2008) states that lymphocytes are an important element in the immune system, which function is to respond to antigens by forming antibodies. Lymphocytes are the type of leukocytes with the most amount in chicken blood. The results of the number of lymphocytes before being treated (Day-0) meet the standards. According to Harahap (2014) that the percentage of lymphocytes in poultry blood ranges from $42 \%-66 \%$. Meanwhile, according to Guyton and Hall (1997) normally the number of lymphocytes is in the range of $24-84 \%$. The lymphocyte test results can be seen in Table 3 .

Data on average lymphocytes on Day-7 in all treatments showed an increase. This is due to the provision of vaccines so that an increase in the number of lymphocytes due to the presence of antigens that enter the body and the possibility of giving meniran and sambiloto extracts have an influence on chicken lymphocytes. Meniran containing flavonoids is used as a booster for the activity of the immunomodulatory system (Suhirman and Winarti 2010) and andrographolide compounds in Bitteroto have good anticancer effects in breast, colon, epidermoid, stomach, cervical, liver, leukemia, myeloma, peripheral blood lymphocytes and prostate cancer (Khumairoh et al., 2013). Data on lymphocytes Day-14 to Day-28 have decreased except in the treatment of menoto-bitter extract composition (50:50\%) there is an increase in lymphocyte levels, but still in standard numbers. The average number of normal lymphocytes is in the range of $24-84 \%$ (Guyton and Hall, 1997). In general, chickens are in good health so chickens are not attacked by Newcastle Disease. As for the consequences caused when infected with ND disease is an increase in the number of lymphocytes exceeds the standard so as to create a high antibody titer to create an immune system against ND disease. The average graph of broiler chicken lymphocytes during treatment can be seen in Illustration 2.

\section{Conclusion}

Based on the results of this study concluded that:

1. Giving of meniran and bitter extracts affect the percentage of abdominal fat, but do not affect feed consumption, final body weight, and carcass percentage. The composition of the extract $25: 75 \%$ decreases the percentage of abdominal fat.

2. Differences in the composition of the meniran and bitter extract can increase antibody titer and maintain the number of chicken lymphocytes under normal conditions

\section{References}

Allan, W. H., J. E. Lancaster and B. Torn. 1978. Newcastle Disease Vaccines. Their Production And Use. Food And Agricultural Organisation. Rome.

Anita, W.Y., I. Astuti dan Suharto. 2012. Pengaruh Pemberian Tepung daun teh tua dalam ransum terhadap performa dan persentase lemak abdominal ayam broiler. Tropical Animal Husbandry Vol. 1 (1), Oktober 2012:1-6

Anonimus, 2015. Mengapa Vaksin ND Aktif Dan Inaktif Dilakukan Secara Bersamaan?.http://dokterternak.com/2015/12/18/mengapa-vaksin-nd-aktif-daninaktif-dilakukan-secara-bersamaan/. Diakses pada 3 Mei 2019 
Beby. 2015. Maternal Antibody. http://bebypratiwy.blogspot.co.id/2015 /06/maternalantibody.html. diakses pada 30 Maret 2019

Bintang, I.A.K. dan A.G. Nataamijaya.2006. Karkas dan Lemak Subkutan Broiler yang Mendapat Ransum dengan Suplementasi Tepung Kunyit (Curcuma domestica val) dan Tepung Lempuyangan (Zingiber aromticum val). Prosiding Seminar Nasional Tekhnologi Peternakan dan Veteriner, Bogor, 5-6 September 2006 Puslitbang Peternakan, Bogor.

Cahyono, M. Indro. 2019. Sejarah, Mitos, dan Fakta tentang Penyakit ND di Indonesia. Poultry Indonesia Maret 2019.

Elfahmi,. 2006. The Indonesian Tradisional Herbal Medicine. www.pom.go.id/oaie/index.asp?aksi=literatur HYPERLINK "http://www.pom.go.id/oaie/index.asp?aksi=literatur\&hlm=1"\& HYPERLINK "http://www.pom.go.id/oaie/index.asp?aksi=literatur\&hlm=1"hlm=1 Diakses pada 18 Oktober 2019.

Fadilah, R. dan Fatkhuroji. 2013. Memaksimalkan Produksi Ayam Ras Petelur. Agromedia Pustaka. Jakarta.

Gillingham S. 2006. General principles of vaccination. http://www.canadianpoultry.ca/ principles_of_vaccination.htm. diunduh 20 September 2019

Guyton, A. C.dan J. E. Hall. 1997. Fisiologi kedokteran. EGC. Jakarta. (Diterjemahkan oleh Irawati, K. A. Tengadi dan A. Santoso).

Harahap, R. A. 2014. Profil Darah Ayam Broiler Periode Finisher Yang Diberi Pakan Plus Formula Herbal. Institut Pertanian Bogor. Bogor

Haro C.V, 2005. Interaction between dietary polyunsaturated fatty acids and vitamin E in body lipid composition and a-tocopherol content of broiler chickens. Thesis. Barcelona.

Khumairoh, Tjandrakirana, Budijastuti W. 2013. Pengaruh Pemberian Filtrat Daun Sambiloto terhadap Jumlah Leukosit Darah Tikus Putih yang Terpapar Benzena. Lentera Berkala Ilmiah Biologi. Januari 2013; Vol. 2(1): 1-5.

Mulyantini. 2010. Ilmu Manajemen Ternak Unggas. Gajah Mada University Press. Yogyakarta

Nahashon, S. N., N. Adefope, A. Amenyenu and D. Wright. 2005. Effects of dietary metabolizable energy and crude protein concentration on growth performance and carcass characteristics of French guinea broiler. Poult. Sci. 84 : 337-344

Rahayu I, Sudaryani T, Santosa. 2011. Panduan Lengkap Ayam. Penebar Swadaya. Jakarta

Rasyaf, M. 2012. Beternak Ayam Pedaging. Penebar Swadaya. Jakarta

Salam, S., A. Fatahilah, D. Sunarti, dan Isroli. 2013. Berat Karkas dan Lemak Abdominal Ayam Broiler yang diberi Tepung Jintan Hitam (Nigella sativa) dalam Ransum selama Musim Panas. Sains Peternakan Vol. 11 (2), September 2013: 8490 
Saputra , H. P, Osfar, S, dan Irfan H. Djunaidi. 2015. Pengaruh Penambahan Fitbiotik Meniran (Phyllanthus niruri L) Dalam Pakan Terhadap Kecernaan Protein Kasar dan Energi Metabolis Ayam Pedaging. Laporan Penelitian. Universitas Brawijaya hal. 3-4.

Setiadi, D., N. Khaira dan T. Syahrio. 2011. Perbandingan bobot hidup, karkas, giblet, dan lemak abdominal ayam jantan tipe medium dengan strain berbeda yang diberi ransum komersial broiler. Skripsi. Jurusan Peternakan. Fakultas Pertanian. Universitas Lampung. Lampung.

Seto, Ridwan. 2019. Menjaga Kulaitas Air Minum. Majalah Infovet April 2019.

Suhirman S, Winarti C. 2010. Prospek dan Fungsi Tanaman Obat Sebagai Imunomodulator. Balai Penelitian Tanaman Obat dan Aromatik dan Balai Besar Penelitian dan Pengembangan Pascapanen Pertanian. Bogor

Sumarni. 2015. Pengaruh kuantitas ransum terhadap persentase karkas, giblet dan lemak abdominal ayam broiler. Skripsi. Fakultas Peternakan. Universitas Halu Oleo.Kendari.

Suprayitno dan M. Indradji.2007. Efektivitas Pemberian Ekstrak Temulawak (Curcumae xanthoriza) dan Kunyit (Curcumae domestica) dan Sebagai Immunostimulator Flu Burung pada Ayam Niaga Pedaging. J. Animal Production.9:178-183.

Tabbu, C.R.2000.Penyakit Ayam dan Penanggulangannya: Penyakit Bakterial, Mikal, dan Viral. Kanisius, Yogyakarta.

Taha, S.R. 2009. Kajian Potensi Ekstrak Tanaman Obat Sambiloto (Andrographis paniculata Ness) dan Beluntas (Pluchea indica Less) Sebagai Alternatif Bahan Obat Flu Burung. Tesis. Fakultas Kedokteran Hewan. Institut Pertanian Bogor.

Wahyu. 2004. Ilmu Nurisi Unggas. Gadjah Mada University Press. Yogyakarta.

Winarto, W.P. 2003. Sambiloto. :Budidaya dan Pemanfaatan Untuk Obat Seri Agri Sehat. Penebar Swadaya. Jakarta.

Yalcinkaya, I., T. Gungor, M. Basalan dan E. Erdem. 2008. Manna Oligosaccharides (MOS) from Saccharomyces cerevisiae in Broilers: Effects on Performance and Blood Chemistry. Turk. J. Vet. Anim. Sci. 